\title{
Polluted lignocellulose-bearing sediments as a resource for marketable goods-a review of potential technologies for biochemical and thermochemical processing and remediation
}

\author{
Henrik Haller ${ }^{1}\left(\mathbb{D} \cdot\right.$ Gabriela Paladino $^{2} \cdot$ Gabriel Dupaul $^{2} \cdot$ Shiromini Gamage ${ }^{2,3} \cdot$ Burdzhu Hadzhaoglu² $^{2}$ \\ Sara Norström ${ }^{4}$ - Alireza Eivazi ${ }^{2} \cdot$ Svante Holm ${ }^{4}$. Erik Hedenström ${ }^{2}$. Anders Jonsson ${ }^{1}$
}

Received: 1 February 2021 / Accepted: 19 June 2021 / Published online: 2 July 2021

(c) The Author(s) 2021

\begin{abstract}
Lignocellulose-bearing sediments are legacies of the previously unregulated wastewater discharge from the pulp and paper industry, causing large quantities of toxic organic waste on the Baltic Sea floor and on the bottom of rivers and lakes. Several $\mathrm{km}^{2}$ are covered with deposits of lignocellulosic residues, typically heavily contaminated with complex mixtures of organic and inorganic pollutants, posing a serious threat to human and ecological health. The high toxicity and the large volume of the polluted material are challenges for remediation endeavours. The lignocellulosic material is also a considerable bioresource with a high energy density, and due to its quantity, it could appeal to commercialization as feedstock for various marketable goods. This study sets out to explore the potential of using this polluted material as a resource for industrial production at the same time as it is detoxified. Information about modern production methods for lignocellulosic material that can be adapted to a polluted feedstock is reviewed. Biochemical methods such as composting, anaerobic digestion, as well as, thermochemical methods, for instance, HTC, HTL, pyrolysis, gasification and torrefaction have been assessed. Potential products from lignocellulose-bearing sediment material include biochar, liquid and gaseous biofuels, growing substrate. The use of a contaminated feedstock may make the process more expensive, but the suggested methods should be seen as an alternative to remediation methods that only involve costs. Several experiments were highlighted that support the conception that combined remediation and generation of marketable goods may be an appropriate way to address polluted lignocellulose-bearing sediments.
\end{abstract}

\section{Graphic abstract}
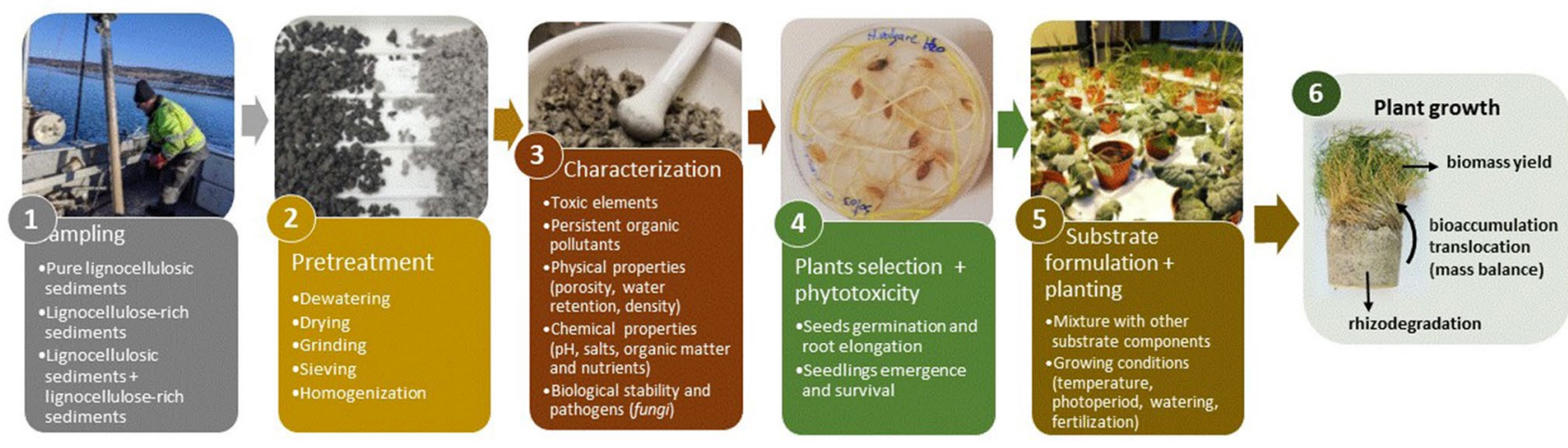

Keywords Lignocellulose-bearing sediments $\cdot$ Sediment Mining $\cdot$ Circular Economy $\cdot$ Ecotechnology $\cdot$ Cleaner Production · Ecotechnology

Extended author information available on the last page of the article 


\section{Introduction}

Environmental degradation causes immense economic losses to society annually and threatens ecosystem functions, human health and food security (Nellemann \& Corcoran 2010; Steffen et al. 2015). More than $60 \%$ of the world's ecosystems are considered degraded (Board 2005), and the ecosystems continue to serve as a sink and receive contaminants from a wide range of sectors. The pressures behind many environmental pollution problems are historical. One such legacy is lignocellulose-bearing sediments, which is an aftermath of the previously unregulated wastewater discharge from the pulp, paper and sawmill industry. Polluted lignocellulosic sediments are an environmental concern of global scale (Hoffman et al. 2019; Owens 1991). USA, Brazil and Canada have the largest three pulp and paper industries in the world, and Sweden comes in the fourth place. The relatively long water residence time in the Baltic Sea makes it susceptible to accumulation of pollutants, and considerable efforts have been made to survey and make inventories of sites of lignocellulose-bearing sediments around the Swedish coast of the Baltic Sea (Dahlberg et al. 2020; Norrlin et al. 2016). Despite that the release of lignocellulose-rich wastewater into rivers, lakes and the Sea has been prohibited in Sweden since 1969, accumulated amounts of lignocellulose-bearing sediments are still present on the Baltic Sea floor and on the bottom of rivers and lakes in Sweden (Severin et al. 2018). An estimated amount of 10.8 million tons of cellulose fibre material was discharged into the aquatic environment in Sweden between 1908 and 1983 (Swedish-EPA 1995).

Two types of lignocellulose-bearing sediments can be distinguished: (1) pure lignocellulosic sediments (often referred to as fibrebanks in the Scandinavian literature); a relatively thick deposit that consists mainly of fibrous residues and wood chips, and (2) lignocellulose-rich sediments, which is a thinner layer of lignocellulosic material, mixed with naturally deposited clayey sediments (Apler et al. 2019). The lignocellulose-bearing sediments are typically heavily polluted by toxic elements (metals and metalloids) and persistent organic pollutants such as polychlorinated biphenyls (PCB), chlorinated pesticides and polycyclic aromatic hydrocarbons (PAH), and they are often located in shallow waters, entailing a serious threat, both to human and ecological welfare (Apler et al. 2019; Dahlberg et al. 2020). Due to the persistence of the pollutants, the lignocellulose-bearing sediments pose a serious pollution problem today, half a century after the latest discharges. In the area of Norrland in Northern Sweden alone, 44 larger sites of hazardous lignocellulose-bearing sediments have been identified within an investigated area of $162 \mathrm{~km}^{2}$. Within the investigated area, the surface area of pure lignocellulosic sediments was estimated to $2,5 \mathrm{~km}^{2}$ and a surface area of $26 \mathrm{~km}^{2}$ was estimated to be constituted of lignocellulose-rich sediments (Norrlin et al. 2016).

The toxic compounds are typically bound to the undisturbed lignocellulose-bearing sediment, but turbulence caused by e.g. boat traffic and waves may cause resuspension of the material into the surrounding water body. Post-glacial and crustal rebound (in the region of Västernorrland, the land masses rise annually between 8 and $10 \mathrm{~mm}$ ) brings the lignocellulose-bearing sediments closer to the sea surface which gradually worsens the problem since the sediments will be increasingly exposed to the turbulence caused by waves and surface activity (Norrlin et al. 2016). Biological activities from benthic microorganisms further exacerbate the problem by emissions of methane and hydrogen sulphide from the anaerobic degradation. Substantial gas emissions have been observed from a number of lignocellulose-bearing sediments in Norrland (Frogner-Kockum et al. 2020). The processes are not well understood, but it is plausible that such internal biological activity within the lignocellulose-bearing sediments in combination with the gas emissions contributes to an increased leaching of toxins into the surrounding waterbody. The methane emissions may furthermore contribute to global warming which is another considerable environmental risk posed by the lignocellulosebearing sediments even though the contribution has not been quantified. The high toxicity and the large volume of the polluted material pose serious challenges to remediation endeavours. However, the lignocellulose-bearing sediments are also a bioresource with a high energy density. Since the material can be found in high quantities, it could appeal to commercialization as feedstock for various bio-based marketable products if detoxified. The creation of profitable products may be decisive to make the remediation of lignocellulose-bearing sediments economically viable.

The population growth and the increasing per capita resource uses increase the pressure on all kinds of resources, including waste material such as forestry residues and other lignocellulosic by-products. Currently, most industrial material flows are linear which causes resource depletion and pollution (Aguilar-Hernandez et al. 2019). When the global share of recovered materials as part of the total resource extraction was quantified for 2015 , it was concluded that $90 \%$ of the world's socio-technological material flows were linear (De Wit et al. 2018). As opposed to this, the concept of circular economy has been proposed where material flows are predominantly cyclic and where production out of waste is encouraged (Kirchherr et al. 2017). The European Green Deal that the European Parliament, adopted in 15 January 2020, and the National strategy for a circular economy, adopted by the Swedish Government in 2020 , call for a 
long-term sustainable transition towards a more efficient and circular resource use (Elkerbout et al. 2020; Ladu et al. 2020).

Although few countries have such a high percentage of forested land cover as Sweden and as much as $10 \%$ of the sawn timber, pulp and paper that is traded on the global market is provided by Sweden (Skogstyrelsen 2015), there is an increasing national competition for wood resources. Considerable quantities of organic residues are generated annually by the forestry and forestryderived industry such as the pulp and paper industry. In Sweden, the pulp and paper industry alone generates 2 million tons of waste per year, which is twice the amount of the waste produced by agriculture, forestry and fishery together (AIS 2018). These resources, historically considered waste, now attain a marketable value as biofuel, peat substitutes, feedstock for composite material, substrate for hydroponics and rearing of insects for protein production, etc. (Ladu et al. 2020; Norgren et al. 2020). Using the detoxified, polluted lignocellulose-bearing sediments as a feedstock for bio-based, marketable goods may thus be a way to alleviate the increasing competition for virgin lignocellulose resources. Potentially, a new value chain can be created at the same time as a pollution problem is addressed. Currently, there is no competition for the lignocellulose-bearing sediment material as a feedstock for industrial use, presumably due to the high costs and potential environmental risk involved with extraction.

Since the slow release of organic and inorganic pollutants to the water and the potentially high amounts of methane produced threatens to transgress the planetary boundaries of climate change and novel entities (Steffen et al. 2015), we conclude that it is not a safe option to let the lignocellulose-bearing sediments remain on the bottom of the Baltic Sea. At present, the material from lignocellulose-bearing sediments may not be an economically competitive alternative to lignocellulosic waste from contemporary industries, but the provision of marketable outputs may make the indispensable remediation venture economically viable. This study sets out to explore the potential of using polluted material from lignocellulosebearing sediments as a feedstock for marketable products. The purpose of this review article is to bring light on the following research questions:

- What biochemical and thermochemical technologies may be appropriate to remediate and produce marketable goods out of polluted lignocellulose-bearing sediment material?

- What constraints do the particular characteristics of polluted lignocellulose-bearing sediment material put in such processes?

\section{Methods}

The literature reviewed in this paper to identify potential processes and marketable bioproducts was obtained from keyword searches in the Scopus, Web of Science and Google Scholar databases using combinations of the key words: 'lignocellulose-bearing sediments', 'paper and pulp mill effluent', 'fibrebank', 'fibre-rich sediments', 'lignocellulosic waste', 'sediment mining', 'POPs', 'heavy metals', 'bioremediation', 'thermochemical processing', 'hydrothermal conversion' 'biorefinery'. Backward reference searching from the 324 references in Dastyar et al. (2019) was used to map technologies for pretreatment and thermochemical conversion of heavy metal-contaminated biomass, and the 267 references cited in Raheem et al (2018) were reviewed to map biological as well as thermochemical treatment technologies. Depending on whether the reviewed technologies had the potential to detoxify and process the feedstock in one or two steps, the processing methods were categorized as:

(1) Cleanup methods that remove or degrade the pollutants as a pretreatment step (section "Pretreatment prior to use in industrial processes")

(2) Combined methods intended to degrade or remove pollutants in the same process that refines the feedstock into marketable goods (section "Biochemical treatments that combine removal/degradation of pollutants with refinery into marketable goods")

The combined methods were further subcategorized based on the research questions as biochemical treatment methods and thermochemical methods.

The inventory of marketable products was based on inhouse experience and multi-stakeholder discussions with actors in the biorefinery sector. Other processing methods and outlets for material from lignocellulose-bearing sediments can be envisaged, most notably as solid fuel, e.g. in combined heat and power plants. However, we have focussed on processed products with a higher commercial value. The review is not intended to be exhaustive. The aim is rather to identify and highlight some options and trends for remediation and processing of material from lignocellulose-bearing sediments into safe marketable goods in order to advance research, innovation and technology in this new field and subsequently to implement these concepts in practice. 
Table 1 Overview of opportunities and constraints associated with the proposed pretreatment and combined process/remediation technologies

\begin{tabular}{l} 
Technology \\
\hline Pretreatments \\
Physicochemical cleanup methods \\
Phytotechnological cleanup methods \\
Combined refinery/remediation (biological \\
treatments)
\end{tabular}

Composting

\section{Mycoremediation/Processing}

\section{Combined refinery/remediation (thermo- chemical treatments)}

Pyrolysis

Gasification

HTL

HTC

Torrefaction
Opportunities

Extraction of a wide range of organic and inorganic pollutants is possible

The process may results in a chemical alteration of the substrate that is favourable for posterior biorefining steps

Typically low cost

Plausible high public acceptance

High-value market niches exist

Can be used for volume reduction as pretreatment step

A wide range of marketable products possible

High lignin content can be an obstacle for fermentation

Can be used for degradation of organic pollutants as well as for metal extraction

Commercially mature method

Produces biochar and syngas

Also polluted biochar has a market niche

Likely to efficiently degrade organic pollutants (but more trials are needed)

Potentially very high capacity of metal removal

High demand for bio-oil

Cost-efficient since there is less need for dewatering

Probably not suitable if high concentrations of metals are present

Cost-efficient since there is less need for dewatering

Organic pollutants may be efficiently degraded

Very high carbon efficiency Primarily commercialized as fuel but many other applications are possible

Primarily commercialized as fuel but many other applications are possible
Constraints

Unsuitable for large volumes due high costs

Inhibitory compounds may be produced that obstruct microbial growth in posterior fermentation steps

Needs to be tailor-made for each specific batch depending on its chemical characteristics

Needs fine tuning before the technology is optimized for lignocellulose sediments

Previous leaching of salts and pollutants may increase costs

Less suitable for substrates where concentration of metals are high

Anaerobic composting methods are immature

Some applications may entail high cost and be unsuitable for large volumes

Difficult to optimize for sediments with a mix of organic/inorganic pollutants

$\mathrm{Cd}$ may end up in the fuel

Metals may end up in the syngas

Optimization is needed for lignocellulosebearing sediments

Little is known about the fate of organic pollutants

Dioxins may be formed due to low temperatures

Still experimental, few mature commercial applications

More research needed on the fate of pollutants 


\section{Results}

Converting polluted biomass from lignocellulose-bearing sediments into clean and innocuous, marketable products are associated with many challenges and potential pitfalls. An overview of opportunities and constraints of the proposed technologies is presented in Table 1 . The extraction of the material from the water and the subsequent dewatering must be conducted in a way that prevents pollutants from leaching to the water. The extraction, dewatering and transport of the material may be energy-intensive endeavours, but from our experience of extracting and dewatering in small-scale mobile units, we conclude that the extraction as well as dewatering can be conducted in close proximity to the source with minimum input of energy and disturbance of the ecosystem. The environmental impact from extraction, dewatering and transport is outside the scope of this article which focusses on the remediation/ value creation process, once the material is on land, but thorough assessments of the previous stages are necessary to evaluate the sustainability potential of the proposed technologies.

\section{Characteristics of the material from lignocellulose-bearing sediments}

The lignocellulose-bearing sediment is characterized by a porous and fibrous structural tissue, comprised primarily of cellulose and lignin. Cellulose and lignin are among the most resistant compounds to microbial degradation in nature. The resistance to degradation that is inherent to lignocellulosic materials gives it unique properties that may be exploited as a feedstock for industrial processing into a number of commercial products (Dobrin et al. 2012; Shmulsky $\&$ Jones 2019). The nutrient content and physical properties of lignocellulose-bearing sediments may vary from one site to another, but typically, the material is characterized by a low density, high porosity and water-holding capacity that resembles peat. If clayey fine sediments are dredged together with the organic material, the physical and chemical properties may be significantly altered however. Table 2 presents some relevant physical and chemical properties of the sediment from one particular site, located in Sundsvall city bay in Sweden collected at $18 \mathrm{~m}$ water depth in the Baltic Sea (WGS84:62''23'32.5"N / 17''23'25.3"E). The characteristics of raw untreated peat serve as reference material.

Since lignocellulose-bearing sediments are characterized by toxic concentrations of organic and inorganic pollutants, special treatment is needed to address the pollution. The remediation of materials co-contaminated with metals and organic pollutants is complex because the required chemical processes and remediation technologies are usually not the same for each group of pollutants (Zhu, Yang et al. 2012).

\section{Pretreatment prior to use in industrial processes}

The concentration of the pollution varies considerably between sediments taken from different locations (Table 3), but most lignocellulose-bearing sediment material needs pretreatment to remove or degrade its pollutants before commercialization. The pretreatment as well as the combined treatments described in 3.3 and 3.4 can be conducted in mobile units close to the source in order to limit the need for transport. The maximum residue level of pollutants that can be permitted depends on the end use of the product. For instance, if the end product is biochar, intended for use as absorbent at landfills or mining sites, low to moderate concentrations of pollution may be tolerated (Haller \& Jonsson 2020), while other end products require a very high purity. The commercial value of the final product determines what price can be justified for the pretreatment. For low value bulk products such as growing substrate, inexpensive but slow and efficient methods may be appropriate. The pretreated material may then be used as virgin lignocellulosic feedstock, but the higher degradability of the pretreated fibres may be favourable in many industrial applications (Baruah et al. 2018; Tayyab et al. 2018).

\section{Physicochemical cleanup methods}

The remediation of pollutants in the lignocellulose-bearing sediments, employing physical and/or chemical procedures to extract toxic elements, commonly known as soil washing or soil extraction, could be a potential pre-treatment to prepare the material as a feedstock for further treatments (Dermont et al. 2008; Ferraro et al. 2016). For instance, pressurized liquid extraction (PLE), supercritical fluid extraction (SFE) and subcritical water extraction are well-established extraction technologies that have applications in the food science and technology, environmental contaminant analysis, fuel industry, etc. (Henry \& Yonker 2006; Herrero et al. 2006). With various degree of selectivity and recoveries/ yields, these treatments are capable to extract a wide range of organic pollutants, including organochlorine pesticides, polycyclic aromatic hydrocarbons, polychlorinated biphenyls and dioxins (Islam et al. 2019; Tagliabue et al. 2020). In the case of subcritical water extraction, heavy metals and metalloids such as $\mathrm{As}, \mathrm{Cd}$ and $\mathrm{Cu}$ can be removed from the matrix without the need of complexing agents (Islam et al. 2019). PLE, SFE and subcritical water extraction are typically not considered for large-scale applications due to their 
Table 2 Physical and chemical properties of material from lignocellulose-bearing sediments in comparison with peat

\begin{tabular}{|c|c|c|}
\hline & $\begin{array}{l}\text { Lignocellulose- } \\
\text { bearing sediment }\end{array}$ & Peat \\
\hline Bulk density $\left(\mathrm{g} / \mathrm{cm}^{3}\right)$ & 0.1 & $0.1-0.2^{\mathrm{a})}$ \\
\hline Air porosity $(\%)$ & 21.1 & $13-24^{(\mathrm{a})}$ \\
\hline Water retention $(\%)$ & 60.6 & $50-80^{(\mathrm{a})}$ \\
\hline Total porosity $(\%)$ & 81.7 & $80-97^{(\mathrm{a})}$ \\
\hline Organic matter (\% Ts) & 92.5 & $89-96^{(\mathrm{a})}$ \\
\hline Ash content (\% Ts) & 7.5 & $4-11^{(\mathrm{a})}$ \\
\hline $\mathrm{pH}_{\mathrm{w}}(1: 10)$ & 5.50 & $3.5-5.5^{(a)}$ \\
\hline Electrical conductivity $(1: 10)(\mathrm{dS} / \mathrm{m})$ & 6.84 & $0.3^{(\mathrm{b})}$ \\
\hline $\begin{array}{l}\text { Total N }(\text { Kjeldahl }+ \text { dewardas })(\mathrm{g} / \mathrm{kg} \\
\text { Ts) Total P }(\mathrm{g} / \mathrm{kg} \mathrm{Ts})\end{array}$ & $6,54,9$ & $7.5^{(\mathrm{b})} 0.5^{(\mathrm{b})}$ \\
\hline $\mathrm{Ca}(\mathrm{g} / \mathrm{kg} \mathrm{Ts})$ & 2,3 & $0.5^{(\mathrm{b})}$ \\
\hline $\mathrm{K}$ (g/kg Ts) & 1,0 & $0.9^{(\mathrm{b})}$ \\
\hline $\operatorname{Mg}(\mathrm{g} / \mathrm{kg} \mathrm{Ts})$ & 2,6 & $0.4^{(\mathrm{b})}$ \\
\hline Total S (g/kg Ts) & 9,8 & - \\
\hline
\end{tabular}

a according to Maher, Prassad et al. (2008) and Jayasinghe et al. (2010)

b according to Jayasinghe et al. (2010)

high cost. Costs for ex situ soil washing technology have been estimated to $\$ 187$ per $\mathrm{m}^{3}$ for large sites and $\$ 70$ per $\mathrm{m}^{3}$ for small sites (FRTR 2021). Other physicochemical cleanup methods include autoclaving, electrokinetic remediation, precipitation and of reducing agents, flotation (Malaviya \& Singh 2011; Wen et al. 2020; Zhang et al. 2019). The high costs associated with many physicochemical cleanup methods make them unsuitable for remediation of large volumes of lignocellulose-bearing sediments, but for smaller batches when high-value end products are envisaged, the higher cost may be justified to ensure an efficient and fast remediation.

Some physicochemical pretreatment methods intended to remove or degrade pollutants may have the additional benefit to alter the chemical composition of the material and make it more suitable for posterior biorefining steps. Increased biodegradability and sugar yield are typical chemical changes associated with physicochemical pretreatment that facilitates microbial fermentation, for instance. Various psychochemical pre-treatment methods have been proved to remove lignin and hemicellulose, release sugars from lignocellulose and decrease the crystallinity of cellulose (Baruah et al. 2018; Tayyab et al. 2018). However, harsh pre-treatment conditions (high temperature, high pressure, high acid/ base concentration) typically enhance the sugar degradation and therefore form inhibitory compounds such as furfural and hydroxymethylfurfural (HMF) that affect the microbial growth in posterior fermentation processes (Chiaramonti et al. 2012; Singh et al. 2015).
Table 3 Some of the pollutants that has been detected in lignocellulose-bearing sediments in the Baltic Sea and the number of samples (modified from Norrlin, Josefsson et al. (2016))

\begin{tabular}{llll}
\hline Elements & Unit & Range & $\mathrm{N}$ \\
\hline $\mathrm{As}$ & mg/kg-TS & $0-6000$ & 144 \\
$\mathrm{Cd}$ & mg/kg-TS & $0-7$ & 144 \\
$\mathrm{Cr}$ & mg/kg-TS & $0-500$ & 144 \\
$\mathrm{Cu}$ & mg/kg-TS & $0-1100$ & 144 \\
$\mathrm{Ni}$ & mg/kg-TS & $0-60$ & 144 \\
$\mathrm{~Pb}$ & mg/kg-TS & $0-900$ & 144 \\
$\mathrm{MeHg}$ & ng/kg-TS & $0-30$ & 140 \\
Organics & & & \\
Sum of PCDD/F-TEQ & ng/kg-TS & $0-600$ & 144 \\
$\mathrm{Hexachlorobenzene}$ & ug/kg-TS & $0-450$ & 144 \\
$\mathrm{DDT}^{\mathrm{HCH}}$ & ug/kg-TS & $0-80$ & 144 \\
$\mathrm{PAH}_{11}$ & ug/kg-TS & $0-18$ & 144 \\
$\mathrm{PCB}_{7}$ & ug/kg-TS & $0-50,000$ & 144 \\
\hline
\end{tabular}

\section{Phytotechnological cleanup methods}

The term phytotechnology implies the use of plants to provide environmental solutions, including phytoremediation options using plants and associated microbes to extract, degrade, contain or immobilize both trace toxic elements and organic pollutants in a polluted medium (Mench et al. 2009). Phytoremediation is a low-cost, safe technology, with high probability of public acceptance that can be adopted to a number of substrates (Lakshman 2016; V. C. Pandey and Bajpai 2019) and may thus be a promising alternative for the cleanup of polluted lignocellulosic waste. As far as we know, there is no reference in the scientific literature to the use of plants for the remediation of polluted lignocellulosebearing sediments.

The physical and chemical properties of this waste material are different from polluted sediments and soils in which phytoremediation is habitually used. When dealing with the treatment of waste materials with unknown characteristics, a stepwise treatability study may aid in reducing failure possibilities and develop the maximum potential of the selected strategy. With the objective of finding appropriate plants for remediation of material from lignocellulose-bearing sediments, the authors of this article developed a stepwise plant screening study, consisting of a profuse literature survey for plants selection, an acute phytotoxicity test of the material on selected plant seeds and a greenhouse bench-scale experiment to assess plants growth and development in potting media prepared with the polluted material. Figure 1 illustrates the pathway followed by our research group for the evaluation of the phytoremediation approach. 
The bioavailability and concentration of the pollutants, as well as biological properties, affects the phytotoxicity of the material for selected phytoremediation plant species. In an ongoing experiment, among other shortlisted species, Brassica juncea, Brassica napus, Horderum vulgare and Pоа аппиа are multi-element hyperaccumulators plants that showed high tolerance to a multi-contaminated (persistent organic pollutants (POP) and inorganic pollutants) and were able to grow with satisfactory biomass yield in soilless potting media prepared with up to $90 \%$ polluted material from lignocellulose-bearing sediments (Paladino et al. 2021). The removal efficiency of toxic elements (in terms of translocation and bioaccumulation factors) and rhizo- or phytodegradation of organic pollutants during plant growth are being quantified at the time of writing. The post-remediation treatment protocol is decisive for the sustainability of phytoremediation technologies (Haller \& Jonsson 2020). An interesting option for the polluted biomass is to use it as a feedstock for the thermochemical methods described in 3.4. Phytoremediation technologies typically need to be tailormade for each particular combination of pollutants. The lack of one-fits-all solutions may be perceived as a barrier for its implementation.

\section{Biochemical treatments that combine removal/ degradation of pollutants with refinery into marketable goods}

Combined methods aimed to integrate degradation and/or removal of the pollutants with processing into marketable goods are potentially cost-effective since no pretreatment is needed. In this article, we have focussed on composting and mycotechnology because of our in-house experience in these fields and the availability of literature on contaminated lignocellulosic municipal solid waste (MSW), etc., that is applicable to material from lignocellulose-bearing sediments. However, many other methods may be suitable.

\section{Composting}

Composting processes have been optimized for varied sources of feedstock, but to date, no composting protocol has been developed for lignocellulose-bearing sediments. Due to its high lignin content, material from lignocellulosebearing sediments is more resistant to decomposition compared to the typical compost sources and longer composting periods are needed than for most agriculture waste or MSW. Experiences from composting of similar lignocellulosic waste such as fibrous forestry residues indicate that composting time can be shortened by thermophilic conditions and N-rich additions of manure, etc. (Raviv 2005; Raviv et al. 1986). Trials are needed to test and fine-tune the optimum mix of feedstock and ideal composting procedure for material from lignocellulose-bearing sediments. Encouraging studies claim that composted organic waste material with similar physical properties such as tree bark, sawdust and sludge produced growing substrates with physical and chemical properties that are equal or even superior to peatbased growing substrate (Fascella 2015; Sánchez-Monedero et al. 2004). The presence of salinity and pollutants in the lignocellulose-bearing sediments needs to be monitored to develop a composting protocol that addresses the specific composition of each batch. If salinity or phytotoxic ions are present, those may be leached by flushing prior to composting. The presence of heavy metals however is much more problematic since their leachability is limited. Composting is capable of complexing, absorbing and (co)precipitating heavy metals (Burgos et al. 2010; Park et al. 2011), but if high concentrations of inorganic pollutants are present, other methods are necessary and composting (if used) should primarily be considered a pre-treatment step to reduce the volume prior to further treatments (Haller \& Jonsson 2020). Organic pollutants, on the other hand, can be degraded with specially designed composting processes (Adams et al. 2015; M. Chen et al. 2015). Composts are typically rich sources of pollutant-degrading microorganisms that can be used to mineralize organic pollutants or transform these into less toxic substances. Composting is reportedly capable of degrading even the most persistent pollutants present in lignocellulose-bearing sediments such as chlorophenols (Laine \& Jorgensen 1996), PAHs (M. Chen et al. 2015) and dichlorodiphenyltrichloroethane (DDT) (Purnomo et al. 2011). Additions of whey are known to speed up the degradation rate of petroleum hydrocarbons (Haller et al. 2020; Jonsson \& Östberg 2011), and other lignocellulosic waste materials, such as corn cobs, sugarcane bagasse and sawdust, have been shown to enhance degradation of many contaminants, including PAHs and organochlorines (Mohee \& Mudhoo 2012). In-depth monitoring programmes of the composting of lignocellulose-bearing sediments are necessary to make sure that the final product is safe to be marketed. If the final compost product only contains permissible levels of pollutants, it may be commercialized as growing substrate. Compost of lower quality may be used on landfills, etc. Significantly less is known about the potential of anaerobic composting of lignin-rich substrates such as material from lignocellulose-bearing sediments, but such methods may prove to have some advantages over aerobic composting ( $\mathrm{T}$. Meyer \& Edwards 2014). For instance, to degrade some of the organochlorine pollutants, an initial anaerobic step may be necessary (Allen et al. 2002; Lacayo et al. 2004).

\section{Mycoremediation/processing}

The role of fungi in the detoxification of the environment is well known. Fungi have properties such as mycelia structure 

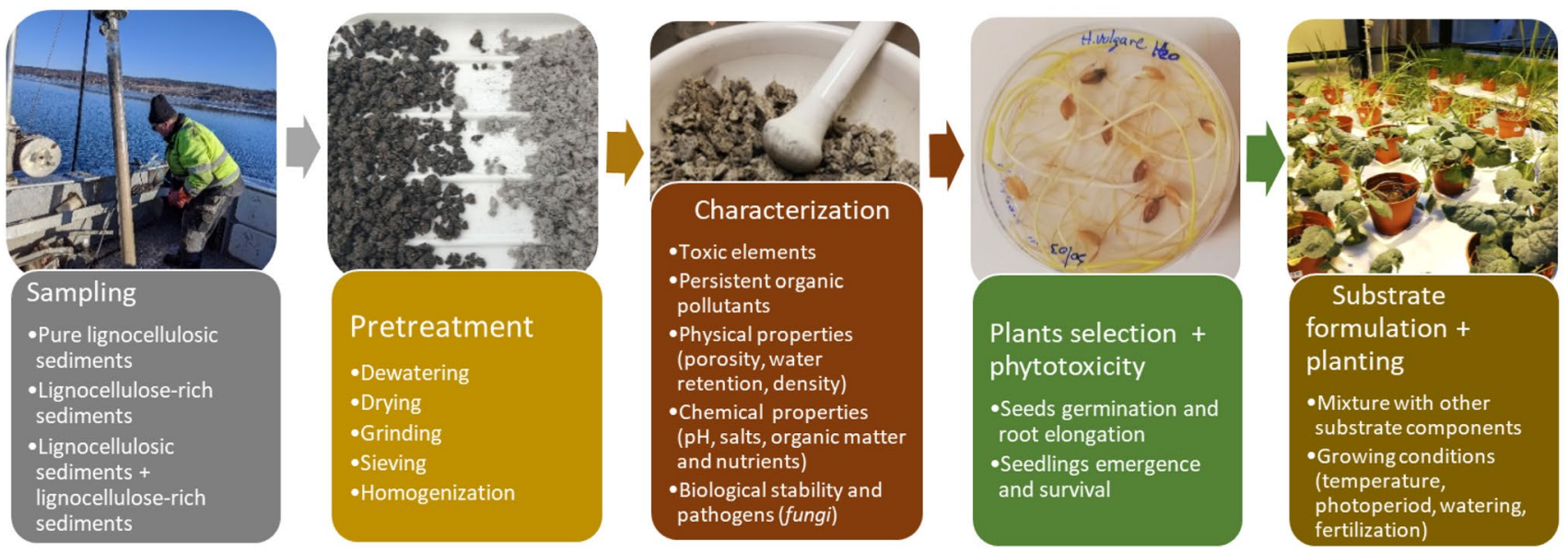

Fig. 1 Evaluation of the phytoremediation approach for pre-treatment of lignocellulose-bearing sediments

and secretion of enzymes and other compounds that makes it interesting for degradation and/or accumulation of pollutants (Gadd 2001; Prasad 2018). Fungal biotechnologies also have the ability to produce a wide range of marketable products including food, feed, chemicals, fuels and textiles (V. Meyer et al. 2020; Yadav 2019). Fungi can thrive in numerous habitats, and white-rot (wood-decaying) and soil-living fungi such as Thermothelomyces thermophila and Fusarium solani can be cultivated directly in the material from lignocellulose-bearing sediments at ambient temperature to assist the degradation of organic pollutants (Perigon, Massier et al. 2019). Smaller batches of lignocellulose-bearing sediments can also be used in bioreactors where oxygen levels, temperature, etc., can be controlled.

Fungi are widely used in fermentative industries for the production of ethanol, organic acids and enzymes (Yadav 2019). The high lignin content of lignocellulose-bearing sediments is an obstacle for the saccharification of cellulose and hemicellulose towards the fermentable sugar production (Chiaramonti et al. 2012; Tayyab et al. 2018). Therefore, lignin removal is essential for the production of monomeric sugars. Some fungi present extracellular lignin-degrading enzymes and cellulase enzyme complex that can be used for delignification and saccharification, respectively (Gupta et al. 2011; R. K. Pandey \& Tewari 2018). This can also be achieved by different pretreatments that are discussed in Sect. 3.2. The main monomeric sugars that can be obtained from lignocellulosic biomass are glucose, xylose, arabinose and mannose, and these can be converted into biofuel such as biodiesel, bioethanol or butanol by further microbial fermentation (Baruah et al. 2018; Tayyab et al. 2018).

White-rot fungi have the ability to biodegrade POPs, absorb metals/metalloids and use lignocellulosic material as a carbon source (Dao et al. 2019; Sharma, Giri, \& Sharma, 2020). In an ongoing experiment conducted by the authors of this article, twenty species of white-rot fungi naturally growing in Sweden are tested for their biodegradation ability of POPs, and bioaccumulation ability of metals/metalloids on material from lignocellulose-bearing sediments taken from Sundsvall Bay (physical and chemical properties are displayed in Table 2). The fungi are growing on hagem-agar discs with material from lignocellulose-bearing sediments. The growth rate of the fungi is recorded with a camera to quantify circular growth, and the POPs degradation will be analysed by gas chromatography-mass spectrometry (GCMS) and metal uptake by high-resolution scanning electron microscopy (HI-SEM) (data not published). If the remediation is successful, selective lignin-degrading white-rot fungi such Phanerochaete chrysosporium may be used to provide an unprotected carbohydrate for subsequent use as animal feed and/or biofuel substrate (Dashtban et al. 2010).

\section{Thermochemical methods that combine removal/degradation of pollutants with refinery into marketable goods}

Thermochemical methods are characterized by faster reaction times and higher conversion efficiency compared to enzymatic or microbial conversion of lignocellulosic biomass to high-value products. To our knowledge, no studies on material from lignocellulose-bearing sediments as a raw material in thermochemical conversion have been published, but experiments with other types of polluted biomass indicate that this could be an appropriate and cost-effective disposal method for lignocellulose-bearing sediments (Dastyar et al. 2019; Haller \& Jonsson 2020). Thermochemical methods have, for example, been shown to be effective in volatilizing (and thus being able to remove), e.g. cadmium and zinc from contaminated biomass (Keller et al. 2005). The higher temperature and longer residence time that are likely 
to be required to promote thermal decomposition of organic pollutants present in lignocellulose-bearing sediments would generate a smaller amount of biochar than in commercial production with non-polluted feedstock. However, this can be compensated by the fact that higher temperatures in turn produce synthesis gas (syngas) in greater quantities and of higher quality (G. Chen et al. 2003; Kan et al. 2016). The authors of this article are currently undertaking experimental research to determine which methods are most appropriate to avoid that toxic compounds end up in final products.

\section{Pyrolysis}

Pyrolysis is a thermochemical technology for converting biomass into energy and marketable products such as liquid bio-oil, solid biochar and pyrolytic gas. The optimum temperature for maximized mixed liquid and solid product yields is in the range of $400-550{ }^{\circ} \mathrm{C}$. Pyrolysis seems to be the thermochemical method where the lowest concentration of pollutants ends up in the marketable goods (Dastyar et al. 2019). Higher temperatures enhance the thermal degradation of organic pollutants and produce higher yield and quality of biogas (Kan et al. 2016). Less biochar is produced with high-temperature pyrolysis, but the biogas production should not be neglected since it can be further converted to hydrogen-rich synthetic gas to be used as fuel directly or as an intermediate resource for production of hydrogen, ammonia, methanol and synthetic hydrocarbon fuels. For lignocellulose-bearing sediments with predominantly inorganic pollutants, lower pyrolysis temperatures may be more suitable. Experiments suggest that in the presence of $\mathrm{Cd}$, it is necessary to operate at temperature lower than $430{ }^{\circ} \mathrm{C}$ to obtain a heavy metals free vapour phase fuel. In the presence of one or more metals among $\mathrm{Pb}, \mathrm{Cu}$ and $\mathrm{Zn}$, on the other hand, it is possible to conduct a pyrolytic treatment at higher temperatures obtaining a char with high surface area and lower metals mobility (Grottola et al. 2019).

\section{Gasification}

Gasification is a technology to convert biomass (or fossil fuel-based feedstock) into gases at elevated temperatures $\left(700-1000{ }^{\circ} \mathrm{C}\right)$ via partial oxidation of compounds using steam, air or oxygen. The principal product is the gas mixture typically denominated syngas (Molino et al. 2018). The high temperatures and pressure used in gasification may lead to volatilization of metals present in the feedstock. The distribution of metals between solid and gaseous state and the quality of syngas produced from gasification are influenced by factors such as i) the chemical speciation of metals and dynamics of fluidization, ii) operating conditions (temperature, pressure, etc.), iii) type of gasifier system (fluidized bed, fixed bed, entrained bed reactors, etc.), iv) impact of fluidized bed materials and v) type of gasification agent (Dastyar et al. 2019). In an experiment conducted by Jiang et al. (2016) As, $\mathrm{Cd}, \mathrm{Zn}$ and $\mathrm{Pb}$ were rapidly volatized at $>600{ }^{\circ} \mathrm{C}$, and $\mathrm{Ni}, \mathrm{Cu}, \mathrm{Mn}$ and Co thoroughly transferred into gaseous phase in the temperature range of $1000-1200{ }^{\circ} \mathrm{C}$, whereas $\mathrm{Cr}, \mathrm{Al}, \mathrm{Fe}$ and $\mathrm{Mg}$ remained immobile in the solid phase at temperatures $>1200{ }^{\circ} \mathrm{C}$. Although experiments suggest that with the exception of $\mathrm{Cd}$, most heavy metals (i.e. $\mathrm{Cu}, \mathrm{Ni}, \mathrm{Pb}$, and $\mathrm{Zn}$ ) typically remain in the solid phase during gasification, in some experiments, high concentrations of metals (such as $\mathrm{Cr}, \mathrm{Ni}, \mathrm{Cu}, \mathrm{Fe}$, and $\mathrm{Mo}$ ) have been observed in the syngas (Cui et al. 2013; TafurMarinos et al. 2014). Trials are thus needed to optimize those parameters in order to obtain clean metal-free products from lignocellulose-bearing sediments. Electrostatic precipitators (ESP) may be used for the collection of solid particles from the gaseous phase in gasification chambers. In an experiment with ESP on contaminated feedstock, at least partial collection of $\mathrm{Cu}, \mathrm{Zn}, \mathrm{Cr}$ and Ni was reported (Poškas et al. 2018). Organic pollutants are likely to be thermally degraded in high-temperature gasification, but trials are needed to develop protocols for gasification of material from lignocellulose-bearing sediments. In particular, the formation of dioxins must be monitored and temperatures above $850{ }^{\circ} \mathrm{C}$ should be used (McKay 2002; Zhou et al. 2015).

\section{Hydrothermal liquefaction}

In hydrothermal liquefaction (HTL), wet biomass slurries are heated to temperatures of $200-500{ }^{\circ} \mathrm{C}$ under high pressure (5-20 Mpa) to produce a mixture of products including bio-oil, gaseous products and a small amount of solids (Gollakota et al. 2018). Thanks to the high content of both nutrients and organics in liquefied products, the resulting products are suitable for further industrial processing into polyol suitable to be used in the formulations of sprayable polyurethane foam, etc. (dos Santos et al. 2018). The HTL process has under optimized conditions removed $\mathrm{Zn}, \mathrm{Pb}$, $\mathrm{Cu}$ from the substrate at an efficiency of $>99 \%$. The metals were found in the water phase, whereas the bio-oil, the commercial product, was free of the analysed metals (Yang 2010). The fate of organic pollutants present in lignocellulose-bearing sediments is yet to be determined. A relative advantage with HTL compared to pyrolysis and gasification is that considerably less dewatering is necessary before it can be used as feedstock.

\section{Hydrothermal carbonization}

Hydrothermal carbonization (HTC) is a technology, appropriate for materials with a high water content, that is performed in a temperature range of $180-350{ }^{\circ} \mathrm{C}$ during which the biomass is submerged in water (and sometimes acids) 
and heated under pressure (2-6 MPa) for 5-240 min. Similar to HTL, expenses for dewatering can be cut with HTC since the feedstock can have a high water content. The main product of HTC is solid (sometimes referred to a hydrochar), but liquid and gaseous (mainly $\mathrm{CO} 2$ ) by-products are also formed (Antero, Alves, de Oliveira, Ojala, \& Brum, 2020; Heidari et al. 2019). HTC is not likely to be suitable for lignocellulose-bearing sediments with high concentration of metals since inorganic pollutants tend to accumulate in the hydrochar (Liu et al. 2018). Organic pollutants (including POPs such as $\beta-\mathrm{HCH}$ ) on the other hand seem to be efficiently degraded in the HTC process (Weiner, Baskyr et al. 2013). The formation of dioxins, however, was not assessed in that study and that may be a serious limitation for sediments polluted with organochlorines.

\section{Torrefaction}

Torrefaction is a thermochemical process that involves the interaction of drying and incomplete pyrolysis at temperatures between 200 and $300{ }^{\circ} \mathrm{C}$. The final products from torrefaction are similar to pyrolysis biochar, but one advantage is that the carbon efficiency (the amount of carbon from the original product that remains in the final product) may be as high as $80-100 \%$ compared to $50 \%$ for pyrolysis (Jorge Miguel Carneiro, Radu, João Carlos de Oliveira, \& Leonel Jorge Ribeiro, 2018; Shankar Tumuluru et al. 2011). The parameters influencing the torrefaction process include (a) reaction temperature, (b) heating rate, (c) absence of oxygen, (d) residence time, (e) ambient pressure, (d) flexible feedstock, (e) feedstock moisture and (f) feedstock particle size (Shankar Tumuluru et al. 2011). Little is known about the fate of pollutants in the torrefaction process, but Edo et al. (2017) report that chlorinated compounds migrated from the feedstock to the gas phase, whereas trace metals remained in the char. Torrefaction of biomass is still to a large extent experimental (Jorge Miguel Carneiro 2018). To date, torrefaction has mainly been assessed for fuel production, but ongoing research is determining its potential to produce an alternative to peat for growing substrate. The hydrophobic behaviour, typical of torrefied biomass however, is a limiting factor for such uses (Rolfsson 2019).

\section{Marketable goods from lignocellulose-bearing sediments}

A number of products can be visualized with detoxified lignocellulose-bearing sediments as a principal feedstock. The commercial value, market segments, size and potential buyers of these products vary widely. An overview of opportunities and constraints associated with such products is presented in Table 4 . Some products are already established on the market, and other novel niche markets are not yet fully exploited. Thorough monitoring of the fate of the pollutants during the industrial processing is necessary to make sure that the use of final products does not expose humans or environment to toxic levels.

\section{Substitute for peat in growing substrate}

The term growing substrate is commonly used to describe materials other than soil that are used to grow plants in a container. Such materials can be inorganic such as rock wool or perlite, but more typically, organic material such as peat is used (Gruda 2011). Peat, however, is a non-renewable resource whose use is problematic from an environmental standpoint, and it plays a major role in carbon capture among other ecosystem services (Biancalani \& Avagyan 2014). Many of the leading peat-production countries located in northern Europe are thus restricting the use of peat (Barrett et al. 2016). Although peat has some physicochemical properties that makes it appropriate for growing substrate, it also has some shortcomings that substrates based on lignocellulose-bearing sediments may actually overcome. The main drawbacks of peat-based substrates are:

1. vehicle for pathogens

2. low available air content

3. instability and shrinkage problems (Gruda 2011).

A peat free substrate based on from lignocellulose-bearing sediments without these drawbacks would likely be a marketable product if pollutants can be effectively removed. Experiments with growing substrates made with alternative feedstock such as composted tree bark, coir dust, green wastes, hulls, sawdust, sewage sludge show that some of these organic materials have physical and chemical properties superior or similar to peat (Fascella 2015). Growing substrates typically receive a medium to low market value, but several sub-niches with high commercial value and considerable market size exist. High-value ornamental plants such as tulips or oriental lilies have traditionally been grown with peat as a substrate. Yet, experiments show that alternative substrates made from composted lignocellulosic materials may present competitive advantages compared to peat, since composted biomass can suppress pathogens, whereas peat is known to be a vehicle for pests (Demir et al. 2010; Jiménez et al. 2012). Another potential sub-niche for growing substrates made from lignocellulose-bearing sediments is the emerging microgreens industry. The grow pads used by microgreens growers are a special niche for substrate producers that may generate a significantly higher income per kg substrate than if sold as a bulk product. Currently, peat-based mixes, coconut coir and synthetic mats are the main substrates for microgreens production, but alternative 
organic fibres have been assessed with promising results (Di Gioia et al. 2017). In order to achieve the optimal balance of air and water-holding capacity for the specific use that is envisaged, growing substrates are often formulated from a blend of different raw materials. The blending of a small fraction of other material than the composted lignocellulosebearing sediments may be crucial to achieve the specific requirements.

\section{Biochar}

The different thermochemical methods suggested in this article all generate char in varying quantities. Biochar (biologically derived charcoal) is a product that has gained interest in the last two decades, because of its potential to sequester atmospheric carbon and thus mitigate climate change as well as its outstanding qualities as a soil amendment (Fraser et al. 2011; Lehmann et al. 2011; Marris 2006). Biochar may be sold as a pure product for soil conditioning or may be mixed in commercial growing substrate blends. Studies have shown that the inclusion of biochar in in growing substrate can enhance cation change capacity (CEC), reduce nutrient losses, improve water-holding capacity (WHC) and provide suitable conditions for beneficial microorganisms (Fascella 2015; Steiner \& Harttung 2014). The presence of metals in the lignocellulose-bearing sediments may be a limiting factor if these are accumulated in the solid phase. However, even polluted biochar may be used as an alternative adsorbent to the traditional activated carbons for removal of molecules and contaminants in aqueous media (Antero et al. 2020). Biochar is an efficient absorbent of toxic metals as well as organic contaminants such as dyes, drugs and pesticides (Antero et al. 2020; Wang et al. 2019). Since the biochar tends to immobilize the metals (Wang et al. 2019), they are prevented from leaching to the environment, but the spent absorbents need to be deposited safely.

\section{Fuel gas}

Syngas is produced by thermochemical conversion, such as pyrolysis or gasification of biomass, or directly from COrich off-gases from industry, e.g. steel mills. The main components of biomass-derived syngas are $\mathrm{CO}, \mathrm{H}_{2}$ and $\mathrm{CO}_{2}$ (B. Pandey et al. 2019). The type of biomass influences the composition and caloric value of the syngas (Molino et al. 2018), and experiments need to be conducted to determine whether the cellulose:hemicellulose + lignin ratio of a particular site with lignocellulose-bearing sediments is appropriate for syngas production. If needed, catalysts such as sodium carbonate and dolomite can be used to promote the gasification of hemicellulose, increase the calorific value of the gas, reduce the tar yield (Yu et al. 2018). The syngas can be combusted directly for power generation and gas engines or used as a raw material for the production of second-generation biofuels, both liquid (such as methanol, ethanol, dimethylether (DME) and Fischer-Tropsch diesel) and gaseous (such as hydrogen and synthetic natural gas, Sikarwar et al. 2016; Tafur-Marinos et al. 2014). The syngas components can also be fermented and converted to alcohols and other chemicals by acetogenic bacteria through the Wood-Ljungdahl pathway or its derivatives (Sun et al. 2019).

\section{Liquid fuels}

Different types of liquid fuels such as lignocellulose-derived ethanol and bio-oil can potentially be made from lignocellulose-bearing sediments. Lignocellulosic ethanol from fermentation of pretreated woody biomass represents one of the main routes for new generation biofuel production (Chiaramonti et al. 2012; Kumar et al. 2009). Bio-oil is a complex mixture of chemical compounds, mostly oxygenates, derived from thermochemical reactions that occur at high temperatures in anaerobic conditions. Due to the instability of the oxygenated compounds, the bio-oil requires deoxygenation as a means of upgrading (Sorunmu et al. 2020). Bio-oil production and upgrading are currently associated with high production costs, but new policies designed to support renewable fuels and the development of more efficient production methods may promote its commercialization in a near future (Kumar and Strezov 2021). Among the aforementioned technologies, HTL seems to be the most promising route for commercially mature bio-oil production (Gollakota et al. 2018).

\section{Substrate for mushroom cultivation and rearing of edible insects}

Insects have become an increasingly interesting food and feed product, in the last decade thanks to a high nutritious value, high feed conversion rate low emission of greenhouse gases. Many wood-eating (xylophagous) insects that utilize wood material as feed are edible and remediated lignocellulose-bearing sediments could potentially be used as a feedstock for such insects. Since thermochemical, mechanical, enzymatical or biological pretreatment of the biomass is typically necessary before its fed to insects (Varelas \& Langton 2017), pretreated lignocellulose sediment is a promising innovative niche that should be further explored. Many cultivated mushrooms use lignocellulosic material as their nutrient source. Detoxified lignocellulose-bearing sediments could consequently be a prime feedstock for mushroom cultivation if the process can guarantee that the residual pollutants do not end up in the edible parts (Grimm \& Wösten 2018; Strapáč et al. 2017). A very high purity is thus needed, and the public acceptance of food produced this way may still be limited. 
Table 4 Overview of some potential marketable goods made from lignocellulose-bearing sediments and some associated opportunities and constraints

\begin{tabular}{|c|c|c|}
\hline Products & Opportunities & Constraints \\
\hline Substitute for peat as a growing substrate & $\begin{array}{l}\text { Sediment-based substrate may be superior to peat } \\
\text { Subniches with high market value }\end{array}$ & $\begin{array}{l}\text { Not currently a market for this products } \\
\text { Customer acceptance unknown } \\
\text { High demands on purity }\end{array}$ \\
\hline Biochar & $\begin{array}{l}\text { Can be produced with different thermochemical } \\
\text { processes } \\
\text { Increasing demand } \\
\text { Carbon sequestration potential } \\
\text { A market niche for contaminated biochar exists }\end{array}$ & Less suitable if metals are present \\
\hline Fuel gas & $\begin{array}{l}\text { Can be generated as main product or coproduct } \\
\text { in different thermochemical processes } \\
\text { Many uses direct and indirect for syngas indus- } \\
\text { trial application }\end{array}$ & $\begin{array}{l}\text { Not known if the lignin }+ \text { hemicellulose:cellulose } \\
\text { ratio is appropriate for syngas production }\end{array}$ \\
\hline Liquid fuels & High demand for liquid biofuels & $\begin{array}{l}\text { Bio-oils often needs upgrading which increases } \\
\text { production costs }\end{array}$ \\
\hline $\begin{array}{l}\text { Substrate for mushroom cultivation and } \\
\text { rearing of edible insects }\end{array}$ & $\begin{array}{l}\text { Increased demand for alternative sources of } \\
\text { protein }\end{array}$ & $\begin{array}{l}\text { High demand for purity } \\
\text { Uncertain public acceptance }\end{array}$ \\
\hline
\end{tabular}

\section{Outlook}

The existence of contaminated lignocellulose-bearing sediments has been well known for decades, yet, very few measures have been taken to address this environmental problem. The reasons why no large-scale remediation projects have been executed include the high costs involved with extraction and remediation and a debate about whether it is safer to cover the polluted sites than to extract them. The methods proposed in this article depart from the standpoint that it is not a safe option to let the lignocellulose-bearing sediments remain on the bottom. The gaseous emissions of hydrogen sulphide and methane and the continuous dissipation of pollutants lead us to the conclusion that extraction is necessary to avoid transgressing the planetary boundaries of climate change and novel entities (Steffen et al. 2015). Extensive caution clearly needs to be taken when the material is extracted since a poorly executed uptake operation risks mobilization of the pollutants.

The methods proposed in this article are based on the view that the detoxified material is a bioresource that can be exploited commercially, which is a strong financial incentive for remediation to take place. The methods should be seen as an alternative to remediation methods that only involve costs. The production of marketable goods is a significant competitive advantage. The methods that we propose are relatively simple and can therefore be developed to be applied in several mobile units that process the material in close proximity to the source, which helps avoiding long and heavy transports associated with disposal. Due to the heterogeneity of the lignocellulose-bearing sediments in terms of concentrations and composition of the pollutants, the methods need to be adapted to the specific conditions reigning at each individual site of lignocellulose-bearing sediment. The lignocellulose-bearing sediment is a finite bioresource whose use cannot be sustained in a circular economy. Its extraction and commercial exploitation is a one-time endeavour that may alleviate a pollution problem created by a historical linear flow of waste from the paper and pulp industry. However, a large-scale application of the technologies that we have proposed in this paper (where a substantial fraction of the estimated $>10.8$ million tons of lignocellulosic waste that was discharged into the Baltic Sea only from Swedish paper and pulp industry) may prevent that an equal amount of virgin lignocellulosic resources to be exploited.

Both the biological and the thermochemical methods proposed in this article are largely based on new combinations of existing technologies and incremental innovation of already functioning solutions and thus relatively close to commercial maturity. Many documented cost-effective phytoextraction/degradation projects have been implemented worldwide during the last decades (Gómez et al. 2019; Pandey and Bajpai 2019) and the fact that many known hyperaccumulating plants survived and even thrived in $90 \%$ material from lignocellulose-bearing sediments as substrate is promising. The cost and remediation of the use of plants to remediate lignocellulose-bearing sediments however is yet to be quantified. Conversion of biomass to biochar, fuel gas and liquid fuel through HTC, HTL, pyrolysis and gasification is currently commercially viable methods. The challenges of using a contaminated feedstock may make the process more 
expensive, but several experiments show that this may still be a promising route (Dastyar et al. 2019; Keller et al. 2005).

Growing substrate, biochar, bio-based fuel gas, liquid fuels and substrate for mushroom cultivation and rearing of edible insects are all well-established products on the international market, and many other potential product niches for lignocellulose-bearing sediments exist. The fact that peat will have to be discontinued and the superiority of some wood-based growing substrates (Gruda 2011) makes a strong sales pitch for growing substrates based on lignocellulose-bearing sediments, but more experiments are needed to understand how these properties can be fully developed and tailor-made for each market segment. The public acceptance of products made from polluted feedstock needs to be further investigated. It is conceivable that some customers are concerned about the safety of such products. On the other hand, environmental policies and public pressure to recycle and reuse industrial by-products on the path towards the development of a circular economy may have a favourable impact on consumer demand (De Wit, Hoogzaad et al. 2018) and stakeholder engagement and transparent information about the production process may mitigate the potential reluctance.

Although the use of technologies that combine remediation and refining of polluted lignocellulose-bearing sediments into marketable goods seems like a promising way forward, a number of potential pitfalls for large-scale applications exist. The following axes of future research were identified as critical in order to surmount such limitations:

- Life cycle assessments of the environmental impact of all stages, necessary to implement the proposed technologies, including extraction, dewatering and transport.

- Development of anaerobic and aerobic composting methods for lignocellulose-bearing sediments.

- Experimental research to determine the efficiency of degradation of POPs during gasification

- Assessment of the environmental fate of organic pollutants in HTL

- Development of effective management protocols for postremediation biomass.

\section{Conclusion}

If detoxified, lignocellulose-bearing sediments can be a bioresource that can be exploited commercially, which is a strong financial incentive for remediation to take place. This study demonstrates the potential of using polluted lignocellulose-bearing sediments as a feedstock for marketable products. The methods should be seen as an alternative to remediation methods that only involve costs. The production of marketable goods such as growing substrate, biochar, bio-based fuel gas, liquid fuels and substrate for mushroom cultivation and rearing of insects is a significant competitive advantage. Conversion of biomass through hydrochemical methods such as HTC, HTL, pyrolysis and gasification or biochemical methods such as composting, phytotechnology and fermentation is currently commercially viable methods. The challenges of using a contaminated feedstock may make the process more expensive, but several experiments show that this may still be a promising route. If the removal of pollutants is efficient and the scale-up of these strategies becomes costs and time effective, the use of technologies that combine remediation and refining of polluted lignocellulose-bearing sediments into marketable goods, it may be an appropriate way to address this major environmental problem.

Funding Open access funding provided by Mid Sweden University. The research has been conducted within the projects BIOREM Fiber, a public-private partnership research project funded by European Regional Development Fund (ERDF) and TERMOSAN funded by Geological Survey of Sweden.

Open Access This article is licensed under a Creative Commons Attribution 4.0 International License, which permits use, sharing, adaptation, distribution and reproduction in any medium or format, as long as you give appropriate credit to the original author(s) and the source, provide a link to the Creative Commons licence, and indicate if changes were made. The images or other third party material in this article are included in the article's Creative Commons licence, unless indicated otherwise in a credit line to the material. If material is not included in the article's Creative Commons licence and your intended use is not permitted by statutory regulation or exceeds the permitted use, you will need to obtain permission directly from the copyright holder. To view a copy of this licence, visit http://creativecommons.org/licenses/by/4.0/.

\section{References}

Adams GO, Fufeyin PT, Okoro SE, Ehinomen I (2015) Bioremediation, biostimulation and bioaugmention: a review. Int J Environ Bioremed Biodegrad 3(1):28-39

Aguilar-Hernandez, G. A., Sigüenza-Sanchez, C. P., Donati, F., Merciai, S., Schmidt, J., Rodrigues, J. F., \& Tukker, A. (2019). The circularity gap of nations: A multiregional analysis of waste generation, recovery, and stock depletion in 2011. Resources, Conservation and Recycling, 151, 104452.

AIS. (2018). Svensk Avfalls hantering 2018. Retrieved from Malmö, Sverige:

Allen, H. L., Torres, M., Shane, D., Hopinkah, D., Eng, S., \& Miller, M. (2002). Rapid removal of toxaphene using anaerobic bioremediation technology. Paper presented at the Proceedings of Third International Conference on Remediation of Chlorinated and Recalcitrant Compound.

Antero, R. V. P., Alves, A. C. F., de Oliveira, S. B., Ojala, S. A., \& Brum, S. S. (2020). Challenges and alternatives for the adequacy of hydrothermal carbonization of lignocellulosic biomass in cleaner production systems: a review. Journal of cleaner production, 252, 119899. 
Apler A, Snowball I, Frogner-Kockum P, Josefsson S (2019) Distribution and dispersal of metals in contaminated fibrous sediments of industrial origin. Chemosphere 215:470-481

Barrett G, Alexander P, Robinson J, Bragg N (2016) Achieving environmentally sustainable growing media for soilless plant cultivation systems-A review. Sci Hortic 212:220-234

Baruah J, Nath BK, Sharma R, Kumar S, Deka RC, Baruah DC, Kalita E (2018) Recent trends in the pretreatment of lignocellulosic biomass for value-added products. Frontiers in Energy Research 6:141

Biancalani, R., \& Avagyan, A. (2014). Towards climate-responsible peatlands management. Retrieved from

Board MA (2005) Millennium ecosystem assessment. New Island, Washington, DC

Burgos P, Madejón P, Cabrera F, Madejón E (2010) By-products as amendment to improve biochemical properties of trace element contaminated soils: Effects in time. Int Biodeterior Biodegrad 64(6):481-488. https://doi.org/10.1016/j.ibiod.2010.05.009

Chen G, Andries J, Luo Z, Spliethoff H (2003) Biomass pyrolysis/gasification for product gas production: the overall investigation of parametric effects. Energy Convers Manage 44(11):1875-1884. https://doi.org/10.1016/S0196-8904(02)00188-7

Chen M, Xu P, Zeng G, Yang C, Huang D, Zhang J (2015) Bioremediation of soils contaminated with polycyclic aromatic hydrocarbons, petroleum, pesticides, chlorophenols and heavy metals by composting: applications, microbes and future research needs. Biotechnol Adv 33(6):745-755. https://doi.org/10.1016/j.biote chadv.2015.05.003

Chiaramonti D, Prussi M, Ferrero S, Oriani L, Ottonello P, Torre P, Cherchi F (2012) Review of pretreatment processes for lignocellulosic ethanol production, and development of an innovative method. Biomass Bioenerg 46:25-35

Cui H, Turn SQ, Keffer V, Evans D, Tran T, Foley M (2013) Study on the fate of metal elements from biomass in a bench-scale fluidized bed gasifier. Fuel 108:1-12

Dahlberg A-K, Apler A, Vogel L, Wiberg K, Josefsson S (2020) Persistent organic pollutants in wood fiber-contaminated sediments from the Baltic Sea. J Soils Sedim 20(5):2471-2483. https://doi. org/10.1007/s11368-020-02610-6

Dao AT, Vonck J, Janssens TK, Dang HT, Brouwer A, de Boer TE (2019) Screening white-rot fungi for bioremediation potential of 2, 3, 7, 8-tetrachlorodibenzo-p-dioxin. Ind Crops Prod 128:153-161

Dashtban M, Schraft H, Syed TA, Qin W (2010) Fungal biodegradation and enzymatic modification of lignin. Int J Biochem Mol Biol 1(1):36

Dastyar W, Raheem A, He J, Zhao M (2019) Biofuel production using thermochemical conversion of heavy metal-contaminated biomass (HMCB) harvested from phytoextraction process. Chem Eng J 358:759-785

De Wit, M., Hoogzaad, J., Ramkumar, S., Friedl, H., \& Douma, A. (2018). The Circularity Gap Report: An analysis of the circular state of the global economy. Circle Economy: Amsterdam, The Netherlands.

Demir, K., Baskent, A., \& Halloran, N. (2010). Effects of different substrates on growth of tulip bulbs under ring culture. Paper presented at the XXVIII International Horticultural Congress on Science and Horticulture for People (IHC2010): International Symposium on 937.

Dermont G, Bergeron M, Mercier G, Richer-Laflèche M (2008) Soil washing for metal removal: a review of physical/chemical technologies and field applications. J Hazard Mater 152(1):1-31

Di Gioia, F., De Bellis, P., Mininni, C., Santamaria, P., \& Serio, F. (2017). Physicochemical, agronomical and microbiological evaluation of alternative growing media for the production of rapini (Brassica rapa L.) microgreens. J Sci Food Agric, 97(4), 1212-1219.

Dobrin, E., Ros U, M., Draghici, E., \& Nechita, P. (2012). Evaluation of potential biodegradation of materials based on peat and waste of cellulose fibres for use in seedling production. Scientific Papers - Series B, Horticulture(56), 89-91.

dos Santos RG, Acero NF, Matos S, Carvalho R, Vale M, Marques AC, Mateus MM (2018) One-component spray polyurethane foam from liquefied pinewood polyols: pursuing eco-friendly materials. J Polym Environ 26(1):91-100

Edo M, Skoglund N, Gao Q, Persson PE, Jansson S (2017) Fate of metals and emissions of organic pollutants from torrefaction of waste wood, MSW, and RDF. Waste Manag 68:646-652. https:// doi.org/10.1016/j.wasman.2017.06.017

Elkerbout, M., Egenhofer, C., Núñez Ferrer, J., Catuti, M., Kustova, I., \& Rizos, V. (2020). The European Green Deal after CoronaImplications for EU climate policy. Retrieved from

Fascella, G. (2015). Growing substrates alternative to peat for ornamental plants. In Soilless culture-Use of substrates for the production of quality horticultural crops: IntechOpen.

Ferraro A, Fabbricino M, van Hullebusch ED, Esposito G, Pirozzi F (2016) Effect of soil/contamination characteristics and process operational conditions on aminopolycarboxylates enhanced soil washing for heavy metals removal: a review. Rev Environ Scie Bio/technol 15(1):111-145

Fraser J, Teixeira W, Falcão N, Woods W, Lehmann J, Junqueira AB (2011) Anthropogenic soils in the central Amazon: from categories to a continuum. Area 43(3):264-273. https://doi.org/10. 1111/j.1475-4762.2011.00999.x

Frogner-Kockum P, Kononets M, Apler A, Hall POJ, Snowball I (2020) Less metal fluxes than expected from fibrous marine sediments. Mar Pollut Bull 150:110750. https://doi.org/10.1016/j.marpolbul. 2019.110750

FRTR. (2021). Remediation Technologies Screening Matrix and Reference Guides, Version 4.0, 4.19 Soil Washing, 4-19 Soil Washing Retrieved January 2021., from Federal Remediation Technologies Roundtable

Gadd, G. M. (2001). Fungi in bioremediation: Cambridge University Press.

Gollakota A, Kishore N, Gu S (2018) A review on hydrothermal liquefaction of biomass. Renew Sustain Energy Rev 81:1378-1392

Gómez, L., Contreras, A., Bolonio, D., Quintana, J., Oñate-Sánchez, L., \& Merino, I. (2019). Phytoremediation with trees. In Advances in Botanical Research (Vol. 89, pp. 281-321): Elsevier.

Grimm D, Wösten H (2018) Mushroom cultivation in the circular economy. Appl Microbiol Biotechnol 102(18):7795-7803. https://doi. org/10.1007/s00253-018-9226-8

Grottola CM, Giudicianni P, Pindozzi S, Stanzione F, Faugno S, Fagnano M, Ragucci R (2019) Steam assisted slow pyrolysis of contaminated biomasses: effect of plant parts and process temperature on heavy metals fate. Waste Manage 85:232-241. https:// doi.org/10.1016/j.wasman.2018.12.028

Gruda, N. (2011). Current and future perspective of growing media in Europe. Paper presented at the V Balkan Symposium on Vegetables and Potatoes 960.

Gupta R, Mehta G, Khasa YP, Kuhad RC (2011) Fungal delignification of lignocellulosic biomass improves the saccharification of cellulosics. Biodegradation 22(4):797-804. https://doi.org/10. 1007/s10532-010-9404-6

Haller H, Jonsson A (2020) Growing food in polluted soils: a review of risks and opportunities associated with combined phytoremediation and food production (CPFP). Chemosphere 254:126826. https://doi.org/10.1016/j.chemosphere.2020.126826

Haller, H., Jonsson, A., Ljunggren, J., \& Hedenström, E. (2020). Appropriate technology for soil remediation in tropical 
low-income countries - a pilot scale test of three different amendments for accelerated biodegradation of diesel fuel in Ultisol. Cogent Environmental Science, 6(1). doi:https://doi.org/10.1080/ 23311843.2020.1754107

Heidari M, Dutta A, Acharya B, Mahmud S (2019) A review of the current knowledge and challenges of hydrothermal carbonization for biomass conversion. J Energy Inst 92(6):1779-1799

Henry MC, Yonker CR (2006) Supercritical fluid chromatography, pressurized liquid extraction, and supercritical fluid extraction. Anal Chem 78(12):3909-3916

Herrero M, Cifuentes A, Ibañez E (2006) Sub-and supercritical fluid extraction of functional ingredients from different natural sources: plants, food-by-products, algae and microalgae: a review. Food Chem 98(1):136-148

Hoffman E, Alimohammadi M, Lyons J, Davis E, Walker TR, Lake CB (2019) Characterization and spatial distribution of organiccontaminated sediment derived from historical industrial effluents. Environ Monit Assess 191(9):1-19

Islam MN, Jo Y-T, Jeong Y-J, Park J-H (2019) Remediation approach for organic compounds and arsenic co-contaminated soil using the pressurized hot water extraction process. Environ Technol 40(1):125-131

Jayasinghe G, Arachchi IL, Tokashiki Y (2010) Evaluation of containerized substrates developed from cattle manure compost and synthetic aggregates for ornamental plant production as a peat alternative. Resour Conserv Recycl 54(12):1412-1418

Jiang Y, Ameh A, Lei M, Duan L, Longhurst P (2016) Solid-gaseous phase transformation of elemental contaminants during the gasification of biomass. Sci Total Environ 563-564:724-730. https:// doi.org/10.1016/j.scitotenv.2015.11.017

Jiménez S, Plaza BM, Segura ML, Contreras JI, Lao MT (2012) Peat Substrate Reuse in Lilium "Helvetia" Crop. Commun Soil Sci Plant Anal 43(1-2):243-250. https://doi.org/10.1080/00103 624.2011 .638585

Jonsson AP, Östberg TL (2011) The effects of carbon sources and micronutrients in whey and fermented whey on the kinetics of phenanthrene biodegradation in diesel contaminated soil. J Hazard Mater 192(3):1171-1177. https://doi.org/10.1016/j. jhazmat.2011.06.024

Jorge Miguel Carneiro, R., Radu, G., João Carlos de Oliveira, M., \& Leonel Jorge Ribeiro, N. (2018). Future Perspectives of Biomass Torrefaction: Review of the Current State-Of-TheArt and Research Development. Sustainability, 10(7), 2323. doi:https://doi.org/10.3390/su10072323

Kan T, Strezov V, Evans TJ (2016) Lignocellulosic biomass pyrolysis: a review of product properties and effects of pyrolysis parameters. Renew Sustain Energy Rev 57:1126-1140. https:// doi.org/10.1016/j.rser.2015.12.185

Keller C, Ludwig C, Davoli F, Wochele J (2005) Thermal treatment of metal-enriched biomass produced from heavy metal phytoextraction. Environ Sci Technol 39(9):3359. https://doi.org/ 10.1021/es0484101

Kirchherr J, Reike D, Hekkert M (2017) Conceptualizing the circular economy: an analysis of 114 definitions. Resour Conserv Recycl 127:221-232

Kumar R, Strezov V (2021) Thermochemical production of bio-oil: A review of downstream processing technologies for bio-oil upgrading, production of hydrogen and high value-added products. Ren Sustain Energy Rev 135:110152. https://doi.org/10. 1016/j.rser.2020.110152

Kumar P, Barrett DM, Delwiche MJ, Stroeve P (2009) Methods for pretreatment of lignocellulosic biomass for efficient hydrolysis and biofuel production. Ind Eng Chem Res 48(8):3713-3729
Lacayo M, van Bavel B, Mattiasson B (2004) Degradation of toxaphene in water during anaerobic and aerobic conditions. Environ Pollut 130(3):437-443

Ladu, L., Imbert, E., Quitzow, R., \& Morone, P. (2020). The role of the policy mix in the transition toward a circular forest bioeconomy. Forest Policy and Economics, 110, 101937.

Laine MM, Jorgensen KS (1996) Straw compost and bioremediated soil as inocula for the bioremediation of chlorophenol-contaminated soil. Appl Environ Microbiol 62(5):1507-1513

Lakshman, H. C. (2016). Phytoremediation: a Strategy to Clean Up Environment: Daya Publishing House.

Lehmann J, Rillig MC, Thies J, Masiello CA, Hockaday WC, Crowley D (2011) Biochar effects on soil biota - A review. Soil Biol Biochem 43(9):1812-1836. https://doi.org/10.1016/j.soilbio. 2011.04.022

Liu T, Liu Z, Zheng Q, Lang Q, Xia Y, Peng N, Gai C (2018) Effect of hydrothermal carbonization on migration and environmental risk of heavy metals in sewage sludge during pyrolysis. Biores Technol 247:282-290. https://doi.org/10.1016/j.biort ech.2017.09.090

Maher, M., Prasad, M., \& Raviv, M. (2008). Organic soilless media components. Soilless culture: Theory and practice, 459-504.

Malaviya P, Singh A (2011) Physicochemical technologies for remediation of chromium-containing waters and wastewaters. Crit Rev Environ Sci Technol 41(12):1111-1172. https://doi.org/ $10.1080 / 10643380903392817$

Marris E (2006) Putting the carbon back: black is the new green. Nature 442(7103):624. https://doi.org/10.1038/442624a

McKay G (2002) Dioxin characterisation, formation and minimisation during municipal solid waste (MSW) incineration: review. Chem Eng J 86(3):343-368. https://doi.org/10.1016/s13858947(01)00228-5

Mench M, Schwitzguébel J-P, Schroeder P, Bert V, Gawronski S, Gupta S (2009) Assessment of successful experiments and limitations of phytotechnologies: contaminant uptake, detoxification and sequestration, and consequences for food safety. Environ Sci Pollut Res 16(7):876. https://doi.org/10.1007/ s11356-009-0252-z

Meyer T, Edwards EA (2014) Anaerobic digestion of pulp and paper mill wastewater and sludge. Water Res 65:321-349. https://doi. org/10.1016/j.watres.2014.07.022

Meyer V, Basenko EY, Benz JP, Braus GH, Caddick MX, Csukai M, Gunde-Cimerman N (2020) Growing a circular economy with fungal biotechnology: a white paper. Fungal Biology and Biotechnology 7:1-23

Mohee, R., \& Mudhoo, A. (2012). Bioremediation and sustainability: research and applications: John Wiley \& Sons.

Molino A, Larocca V, Chianese S, Musmarra D (2018) Biofuels production by biomass gasification: a review. Energies 11(4):811

Nellemann, C., \& Corcoran, E. (2010). Dead planet, living planet: biodiversity and ecosystem restoration for sustainable development: United Nations Environment Programme (UNEP).

Norgren R, Björkqvist O, Jonsson A (2020) Bio-sludge from the pulp and paper industry as feed for black soldier fly larvae: a study of critical factors for growth and survival. Waste and Biomass Valorization 11(11):5679-5685

Norrlin, J., Josefsson, S., Larsson, O., \& Gottby, L. (2016). Mapping and Risk Classification of Fiberbanks in Northern Sweden. Report 2016:21 (in Swedish). Retrieved from Uppsala:

Owens JW (1991) The hazard assessment of pulp and paper effluents in the aquatic environment: a review. Environm Toxicol Chem Int J 10(12):1511-1540 
Paladino, G., Dupal, G., Haller, H., Gamage, S., Hadzhaoglu, B., Norström, S., . . Hedenström, E. (2021). Evaluation of strategies for ex situ phytoremediation of fiber bank material unpublished data.

Pandey B, Prajapati YK, Sheth PN (2019) Recent progress in thermochemical techniques to produce hydrogen gas from biomass: a state of the art review. Int J Hydrogen Energy 44(47):25384-25415

Pandey, R. K., \& Tewari, L. (2018). Mycotechnology for lignocellulosic bioethanol production: An emerging approach to sustainable environment. In Microbial Biotechnology in Environmental Monitoring and Cleanup (pp. 28-43): IGI Global.

Pandey, V. C., \& Bajpai, O. (2019). Phytoremediation: From theory toward practice. In Phytomanagement of Polluted Sites (pp. 1-49): Elsevier.

Park JH, Lamb D, Paneerselvam P, Choppala G, Bolan N, Chung JW (2011) Role of organic amendments on enhanced bioremediation of heavy metal(loid) contaminated soils. J Hazard Mater 185(2-3):549-574

Poškas R, Sirvydas A, Poškas P, Jouhara H, Striūgas N, Pedišius N, Valinčius V (2018) Investigation of warm gas clean-up of biofuel flue and producer gas using electrostatic precipitator. Energy 143:943-949

Prasad, R. (2018). Mycoremediation and environmental sustainability: Springer.

Purnomo AS, Mori T, Kamei I, Kondo R (2011) Basic studies and applications on bioremediation of DDT: a review. Int Biodeterior Biodegrad 65(7):921-930. https://doi.org/10.1016/j.ibiod. 2011.07.011

Raheem A, Sikarwar VS, He J, Dastyar W, Dionysiou DD, Wang W, Zhao M (2018) Opportunities and challenges in sustainable treatment and resource reuse of sewage sludge: a review. Chem Eng J 337:616-641

Raviv M (2005) Production of high-quality composts for horticultural purposes: a mini-review. Production of High-Quality Composts for Horticultural Purposes: a Mini-Review 15(1):52-57

Raviv M, Chen Y, Inbar Y (1986) Peat and peat substitutes as growth media for container-grown plants. In: Chen Y, Avnimelech Y (eds) The Role of Organic Matter in Modern Agriculture. Springer, Netherlands, Dordrecht, pp 257-287

Rolfsson, H. (2019, 7 Juni). GROT kan ersätta torven i trädgården. Land Skogsbruk.

Sánchez-Monedero MA, Roig A, Cegarra J, Bernal MP, Noguera P, Abad M, Antón A (2004) Composts as media constituents for vegetable transplant production. Compost Science \& Utilization 12(2):161-168. https://doi.org/10.1080/1065657x.2004.10702 175

Severin, M., Josefsson, S., Nilsson, P., Ohlsson, Y., Stjärne, A., \& Wernersson, A.-S. (2018). Förorenade sediment-behov och färdplan för en renare vattenmiljö.

Shankar Tumuluru J, Sokhansanj S, Hess JR, Wright CT, Boardman RD (2011) A review on biomass torrefaction process and product properties for energy applications. Ind Biotechnol 7(5):384-401

Sharma K, Giri R, Sharma R (2020) Lead, cadmium and nickel removal efficiency of white-rot fungus Phlebia brevispora. Lett Appl Microbiol 71(6):637-644

Shmulsky, R., \& Jones, P. D. (2019). Forest products and wood science: an introduction: John Wiley \& Sons.

Sikarwar VS, Zhao M, Clough P, Yao J, Zhong X, Memon MZ, Fennell PS (2016) An overview of advances in biomass gasification. Energy Environ Sci 9(10):2939-2977

Singh J, Suhag M, Dhaka A (2015) Augmented digestion of lignocellulose by steam explosion, acid and alkaline pretreatment methods: a review. Carbohyd Polym 117:624-631

Skogstyrelsen. (2015). Forests and Forestry in Sweden. In. Stockholm: Skogstyrelsen.
Sorunmu Y, Billen P, Spatari S (2020) A review of thermochemical upgrading of pyrolysis bio-oil: Techno-economic analysis, life cycle assessment, and technology readiness. GCB Bioenergy 12(1):4-18

Steffen W, Richardson K, Rockström J, Cornell SE, Fetzer I, Bennett EM, de Wit CA (2015) Planetary boundaries: Guiding human development on a changing planet. Science 347(6223):1259855

Steiner C, Harttung T (2014) Biochar as a growing media additive and peat substitute. Solid Earth 5(2):995-999

Strapáč I, Kuruc M, Baranová M (2017) Determination of antioxidant parameters of pleurotus mushrooms growing on different wood substrates. Folia Veterinaria 61(4):53-58. https://doi.org/10. 1515/fv-2017-0039

Sun X, Atiyeh HK, Huhnke RL, Tanner RS (2019) Syngas fermentation process development for production of biofuels and chemicals: a review. Bioresource Technology Reports 7:100279. https://doi. org/10.1016/j.biteb.2019.100279

Swedish-EPA. (1995). Branchkartläggningen, en översiktlig kartläggning av efterbehandlingsbehovet i Sverige, efterbehandling och sanering.

\section{Report no 4393}

Tafur-Marinos JA, Ginepro M, Pastero L, Torazzo A, Paschetta E, Fabbri D, Zelano V (2014) Comparison of inorganic constituents in bottom and fly residues from pelletised wood pyro-gasification. Fuel 119:157-162

Tagliabue M, Grande M, Perucchini S, Bellettato M, Montanari E (2020) Removal of chlorinated pesticide contamination by soil washing with sole water. SN Appl Sci 2(4):1-4

Tayyab M, Noman A, Islam W, Waheed S, Arafat Y, Ali F, Lin W (2018) Bioethanol production from lignocellulosic biomass by environment-friendly pretreatment methods: a review. Appl Ecol Env Res 16:225-249

Wang L, Chang Y, Liu Q (2019) Fate and distribution of nutrients and heavy metals during hydrothermal carbonization of sewage sludge with implication to land application. J Clean Prod 225:972-983. https://doi.org/10.1016/j.jclepro.2019.03.347

Varelas V, Langton M (2017) Forest biomass waste as a potential innovative source for rearing edible insects for food and feed - A review. Innov Food Sci Emerg Technol 41:193-205. https://doi. org/10.1016/j.ifset.2017.03.007

Wen, D., Fu, R., \& Li, Q. (2020). Removal of inorganic contaminants in soil by electrokinetic remediation technologies: A review. Journal of Hazardous Materials, 123345.

Yadav, A. N. (2019). Fungal white biotechnology: conclusion and future prospects. In Recent advancement in white biotechnology through fungi (pp. 491-498): Springer.

Yang J-G (2010) Heavy metal removal and crude bio-oil upgrading from Sedum plumbizincicola harvest using hydrothermal upgrading process. Biores Technol 101(19):7653-7657

Yu H, Wu Z, Chen G (2018) Catalytic gasification characteristics of cellulose, hemicellulose and lignin. Renewable Energy 121:559567. https://doi.org/10.1016/j.renene.2018.01.047

Zhang Y, Zuo S, Zhang Y, Ren G, Pan Y, Zhang Q, Zhou M (2019) Simultaneous removal of tetracycline and disinfection by a flowthrough electro-peroxone process for reclamation from municipal secondary effluent. J Hazard Mater 368:771-777

Zhou H, Meng A, Long Y, Li Q, Zhang Y (2015) A review of dioxinrelated substances during municipal solid waste incineration. Waste Manage 36:106-118. https://doi.org/10.1016/j.wasman. 2014.11.011 
Zhu Z-Q, Yang X-E, Wang K, Huang H-G, Zhang X, Fang H, He Z-L (2012) Bioremediation of Cd-DDT co-contaminated soil using the Cd-hyperaccumulator Sedum alfredii and DDT-degrading microbes. J Hazard Mater 235:144-151
Publisher's Note Springer Nature remains neutral with regard to jurisdictional claims in published maps and institutional affiliations.

\section{Authors and Affiliations}

\section{Henrik Haller ${ }^{1}$. $\cdot$ Gabriela Paladino $^{2} \cdot$ Gabriel Dupaul $^{2}$. Shiromini Gamage ${ }^{2,3}$ - Burdzhu Hadzhaoglu²} Sara Norström ${ }^{4}$ - Alireza Eivazi ${ }^{2}$. Svante Holm $^{4}$ - Erik Hedenström ${ }^{2}$ • Anders Jonsson ${ }^{1}$

$\triangle$ Henrik Haller henrik.haller@miun.se

1 Department of Ecotechnology and Sustainable Building Engineering, Mid Sweden University, Östersund, Sweden

2 Department of Chemical Engineering, Mid Sweden University, Sundsvall, Sweden
3 Colabitoil Sweden AB, Norrsundet, Sweden

4 Department of Natural Sciences, Mid Sweden University, Sundsvall, Sweden 